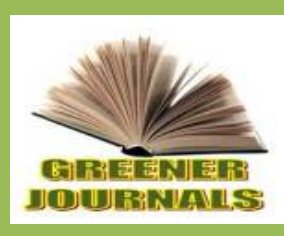

\title{
Egg Production and Quality Traits of Layers kept in Free Range Housing System
}

\section{Hakan Yıldırım¹, Şerafettin Kaya ${ }^{1 *}$}

${ }^{1}$ Mustafa Kemal University, Agriculture Faculty, Animal Science Department, 31060, HATAY/ TURKEY

ARTICLE INFO

Article No.: 032217041

DOI: 10.15580/GJAS.2017.2.032217041

Submitted: $22 / 03 / 2017$

Accepted: 07/03/2017

Published: 04/04/2017

${ }^{\star}$ Corresponding Author

Şerafettin Kaya

E-mail: serafettinkaya@gmail. com

\section{Keywords:}

Egg quality, egg yield, free range, indoor, layer
The objective of this study was to compare egg quality and yield in laying hens of two different housing systems indoor and free range.

In this study, $120 \mathrm{H} \& \mathrm{~N}$ (Nick-Chick) white egg layer pullets were used. They were divided to equally two groups free range and indoor housing system. Indoor birds were individually caged while free range birds were allowed to access free range grass paddock (red clover+ fescue + brome grass area, $4 \mathrm{~m}^{2} / 1$ bird) plus floored area with wooden shavings. Standard feeding regimen was applied on experimental laying hens. Their egg traits were recorded during the period of 2146 weeks old. Housing system has a significant effect on layer final body weight $(P<0.01)$. Free range group was higher than indoor group about total egg/month, hen/house and hen \% when egg yield compare to the groups. Egg weight was higher in indoor group (59.04-60.22 g), but shell thickness (0.38-0.37 mm) and yolk index (46.07-44.91) were higher free range system $(P<0.01)$. Housing systems have not significant effects on other egg characteristics such as shell ratio, shape index and albumen index. 


\section{INTRODUCTION}

Nowadays consumers have shown the tendency to consume natural, no added on, unprocessed foods or roughly processed foods. The management conditions affecting animal's health and status, the changes in egg content either positive or negative have affected the food preferences of consumers (Şekeroğlu and Sarıca, 2005). For this reason, consumer has preferred the poultry foods produced in free range condition or village condition rather than in cage system.

Although Kouba (2003) mentioned that organic eggs are more tasteful, safe and nutritious for consumers, egg quality and its content are affected by husbandry systems (Küçükyılmaz et al., 2012; Englmaierova et al. 2014), genetics, health status of animal, dietary content and environmental conditions (Hammershoj and Steenfeldt, 2015). When animals kept on in free range, the obtained eggs' shell strength and egg weight were affected significantly (Van de Brannt et al. 2004; Krawczyk et al. 2005).

There have been some studies reporting free range eggs were heavier than those from caged layers (Hughes et al. 1985; Hidalgo et al. 2008) while the other reports mentioned the smaller eggs were produced in free range system compared to cage system (Mostert et al. 1995; Pavlovski et al. 1992, 1994).

In the current study, the egg production performance and egg qualities of free range and indoor housed laying hens were tried to be compared.

\section{MATERIALS AND METHODS}

This trial was carried out at the poultry unit of research farm of Mustafa Kemal University, Hatay, Turkey with approval from the animal ethics committee of the University of Mustafa Kemal (protocol numbers 201401/6). As animal material, $120 \mathrm{H} \& \mathrm{~N}$ (Nick-Chick) white egg layer pullets were used. They were all vaccinated before transferring experimental unit at 13 weeks old. They were divided to two groups free range and indoor housing system. Each group included 60 birds. Indoor birds were individually caged while free range birds were allowed to access free range grass paddock (red clover+ fescue + brome grass area, $4 \mathrm{~m}^{2} / 1$ bird) plus floored area with wooden shavings. Standard feeding regimen was applied on experimental laying hens. Birds were fed on a layer diet including $2800 \mathrm{Kcal}$ ME and $170 \mathrm{~g}$ crude protein per $\mathrm{kg}$ during the period of 1836 weeks old while they were fed on a diet including $2800 \mathrm{Kcal} \mathrm{ME}$ and $160 \mathrm{~g}$ crude protein per $\mathrm{kg}$ diet during the period of 36-52 weeks old. Their egg traits were recorded during the period of 21-46 weeks old although the experiment started from 13 weeks old and continued to 46 weeks old.

Animals were subjected to 16 hours illumination. In layer hens, egg production performance parameters (feed intake, egg yield, feed conservation ratio) and egg quality traits (egg weight, shape index, shell thickness, shell weight, breaking resistance, white index, yellow index, haugh unit, yolk colour) were determined on weekly basis.

Eggs were collected daily and egg yield was recorded. For each housing system, daily 5 eggs (7 days $\times 2$ housing systems $\times 25$ weeks, totally 1750 eggs) were evaluated for inner and outer egg quality criteria.

Experimental hens were allowed to consume daily $110 \mathrm{~g}$ feed as based on the feeding management manual of layer genotype. The body weight of hen was monitored monthly to calculate the changes in body weight from the last weighing to prior one. Feed conversion ratio was calculated by dividing egg mass to the consumed feed. Egg weights were determined weekly by using $0.01 \mathrm{~g}$ sensitive scale.

Egg production was calculated daily, weekly and monthly hen-housed basis as given the formula below;

Total number of eggs laid during the period

Hen housed egg production $=$---otal number of hens housed at the beginning of laying period

The measurement of the sizes of eggs were done by using Vernier caliper, the heights of albumen and yolk were measured by using a micrometer with three points. Shell thickness also was measured by using micrometer by calculating the mean thickness of taking measurements lateral ends and equator points of dried egg shell.

The formulae or equations for the calculation of the parameters of inner and outer egg qualities are given below as cited from Sarıca and Erensayın (2009).

Shape index $(\%)=($ Egg size $/$ Egg length $) \times 100$

Shell rate $(\%)=$ (shell weight $/$ egg weight $) \times 100$

Haugh Unit = 100x log $\left(H+7.57-1.7 \times W^{0.37}\right)$;

Here, $\quad \mathrm{H}=$ albumin height $(\mathrm{mm}), \mathrm{W}=$ egg weight $(\mathrm{g})$

Albumen height $(\mathrm{mm}) \times 100$

\begin{tabular}{|c|c|}
\hline 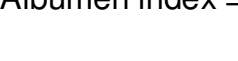 & [Albumen length $(\mathrm{mm})+$ Albumen size $(\mathrm{mm})] / 2$ \\
\hline & Yolk height $(\mathrm{mm}) \times 100$ \\
\hline
\end{tabular}


The mathematical model of experiment as following;

$Y i j=\mu+\alpha i+e i j$

In which;

Yij; $i^{\text {th }}$ housing group and $j^{\text {th }}$ animal's data

$\mu$; mean of population

ai; $i^{\text {th }}$ effect of housing

eij; error

The data were statistically evaluated by using One Way ANOVA procedure of SPSS software (Kinnear and Gray, 1994).

\section{RESULTS AND DISCUSSION}

In this study, experimental hens were fed on experimental diet based on nutritional manual of their belonging breed (110 $\mathrm{g}$ feed allowance per day).

The experimental hens did not change their body weights and kept their live weights in the standards of their belonging breed body weight standards. However, according to Table 1, indoor hens lost much live weight than free range ones $(P<0.01)$.

Even though there is difference between live weights of experimental hens at the end of experiment $(P<0.01)$, these live weights were between the manual of experimental breed' live weight range 1205-1708 g.

Table 1. The live weight changes of experimental hens housed in free range and indoor housing systems

\begin{tabular}{|l|c|c|c|c|}
\hline Parameter & Free range & Indoor & SEM & P values \\
\hline Initial live weight, g/hen & 1512.66 & 1509.33 & 9.70 & 0.865 \\
\hline Final live weight, g/hen & 1572.14 & 1407.79 & 18.01 & 0.000 \\
\hline
\end{tabular}

Monthly egg production, hen-housed egg production and hen-day egg production values are given in Table 2. The first eggs were seen at $18^{\text {th }}$ week of age and 50 $\%$ egg production occurred in free range hens in $21^{\text {st }}$ week (on $147^{\text {th }}$ day) and in indoor hens was seen in $22^{\text {nd }}$ week (on $154^{\text {th }}$ day). According to the manual of this egg type pullet, $50 \%$ egg production should have been on 140-150 days.

Table 2. Total egg production of layers housed differently

\begin{tabular}{|l|l|l|r|r|r|r|}
\hline \multirow{2}{*}{ Months } & \multicolumn{3}{|c|}{ Free range } & \multicolumn{3}{c|}{ Indoor } \\
\cline { 2 - 8 } & $\begin{array}{l}\text { Egg } \\
\text { count } \\
\text { per } \\
\text { month }\end{array}$ & $\begin{array}{l}\text { Hen } \\
\text { housed egg } \\
\text { production }\end{array}$ & $\begin{array}{l}\text { Hen-day } \\
\text { egg } \\
\text { production } \\
\text { \% }\end{array}$ & $\begin{array}{l}\text { Egg } \\
\text { count } \\
\text { per } \\
\text { month }\end{array}$ & $\begin{array}{l}\text { Hen } \\
\text { housed egg } \\
\text { production }\end{array}$ & $\begin{array}{l}\text { Hen-day } \\
\text { egg } \\
\text { production } \\
\%\end{array}$ \\
\hline Nov 2014 & 85 & 1.41 & 4.7 & 62 & 1.03 & 3.43 \\
\hline Dec 2014 & 1492 & 24.86 & 82.66 & 1169 & 19.48 & 64.93 \\
\hline Jan 2015 & 1775 & 29.58 & 98.6 & 1649 & 27.48 & 91.6 \\
\hline Feb 2015 & 1603 & 26.71 & 89.03 & 1433 & 24.28 & 80.93 \\
\hline Mar 2015 & 1770 & 30.00 & 100.00 & 1615 & 27.37 & 91.23 \\
\hline April 2015 & 1593 & 27.94 & 93.13 & 1487 & 25.20 & 84.00 \\
\hline May 2015 & 1331 & 24.2 & 80.66 & 1308 & 22.55 & 75.16 \\
\hline
\end{tabular}

With respect to monthly and total egg production, free range hens produced the higher amount of egg compared to indoor ones. For example, in March 2015 season, free range hens' egg production reached $100 \%$ hen-day production while indoor hens' the highest egg production was $\% 91.23$.
Both free range and indoor hen evaluated the feeds nearly same as seen the nearly equally feed conversation ratios $1.94 \pm 0.07$ vs $1.90 \pm 0.07$, respectively without significant statistical significant.

The egg quality traits of experimental hens are given in Table 3. 
Table 3. Egg quality traits in layers housed differently

\begin{tabular}{|l|c|c|}
\hline Parameter & Free range & Indoor \\
\hline Egg weight $(\mathrm{g})$ & $59.04 \pm 4.15$ & $60.22 \pm 3.45^{\star}$ \\
\hline Shell thickness $(\mathrm{mm})$ & $0.38 \pm 0.03$ & $0.37 \pm 0.03^{\star}$ \\
\hline Shell rate (\%) & $10.39 \pm 0.71$ & $10.41 \pm 0.69$ \\
\hline Shape index & $76.00 \pm 2.01$ & $76.24 \pm 2.34^{*}$ \\
\hline Albumen index & $2.59 \pm 0.64$ & $2.36 \pm 0.61^{\star}$ \\
\hline Yolk index & $46.07 \pm 5.06$ & $44.91 \pm 4.78^{*}$ \\
\hline Haugh unit & $87.38 \pm 10.48$ & $84.83 \pm 11.45^{\star *}$ \\
\hline
\end{tabular}

${ }^{*}$ Means with the same row different superscripts are significantly different $\left(\mathrm{P}<0.05^{*}\right.$ or $\left.\mathrm{P}<0.01^{* *}\right)$

Previous studies showed that production systems affected egg weight, evidenced by lighter eggs in cage system (Uluocak 1991; Anderson and Adams 1994; Leyendecker et al. 2001; Sarıca and Erensayın 2009; Englmaierova et al. 2014), on the contrary of some reports on lighter eggs in free range systems compared to cage system (Keeling and Dun 1988; Pavlovski et al. 1994; Mostert et al. 1995; Tumova and Ebeid 2005; Pistekova et al. 2006).

Indoor hens produced heavier eggs compared to free range hens $(P<0.05)$. Both free range and indoor hens produced eggs in the range of standards, in average $57.6 \mathrm{~g}$ according to the study of Sarıca and Erensayın (2009).

While shell rate was not significantly between groups $(P>0.05)$, shell thickness, albumen and yolk indexes were higher in free range eggs than indoor eggs, and shape index value of indoor eggs was greater than free range eggs $(P<0.05)$.

Shape index is calculated the size of egg by dividing its length. The ideal egg shape value for edible and hatching eggs is $74 \%$ (Sarıca and Erensayın

\begin{tabular}{lrl} 
& A Class & B Class \\
\hline Extra fresh & $\geq 72$ & $\leq 50$ \\
Out of extra fresh $=71-50$ &
\end{tabular}

As shown in Table 3, Haugh unit value was $87.38 \pm 10.48$ in free range eggs and $84.83 \pm 11.45$ in indoor eggs. Even though this was higher value in former eggs than latter eggs, these values were between the standards of TSE on the rank of extra fresh $A$.

It was observed that yolk colour scale (Roche Colour Fan) was 12 for both experimental group free range and indoor eggs without any significant difference.

Free range hens were heavier than indoor ones at the end of experiment while both group hens' body weight changes were in given ranges in its breeder management manual.

According to experimental layer hen's manual, $50 \%$ egg production age should be on (between) 140$150^{\text {th }}$ days, actually this was happened on $147^{\text {th }}$ day for free range hens and on $154^{\text {th }}$ day for indoor hens.

On monthly basis, free range birds produced more eggs compared to indoor hens.
2009). If shape index is higher than $76 \%$, these eggs will be defined oval, if $72-76 \%$, these will be defined normal eggs and $<72 \%$, these eggs will be defined longer. Our experimental eggs were defined normal eggs according to shape index value.

Normal egg shell thickness is between 0.30$0.35 \mathrm{~mm}$. Our experimental eggs had shells having 0.37-0.38 mm thickness which was above of ideal.

Yolk index shows the rigidity of yolk for standing up without spreading on the surface and it should be between 36-44 in fresh egg (Mineki and Kobayashi 1998). However, Doğan (2008) stated that it should be between 40-46, while Sarıca and Erensayın (2009) reported that above 46. In the current study, egg yolk shape index was calculated as $46.07 \pm 5.06$ for free range eggs and $44.91 \pm 4.78$ for indoor eggs.

According to Turkish Institution of Standards, our experimental eggs were classified $A$ and $B$ class eggs with respect to Haugh Unit values (Anonymous 2015).

Experimental animals were allowed to consume daily $110 \mathrm{~g}$ layer diet according to egg layer hybrid manual. Feed conversion rate was 1.94 in free range hens and this was 1.90 in indoor hens. This slight difference was related to the weights of produced eggs in that free range hens produced lighter eggs (59.04 g) compared to indoor hens $(60.22 \mathrm{~g})$.

\section{CONCLUSION}

Results showed that, both eggs whether in free range or indoor production system were nearly same with respect to the preference of consumers and general appearance or looking and production yield. In this study, we maybe breakdown the prejudice of consumer to buy eggs produced in conventional way, i.e., in cages by showing them the production chains in both systems and why free range eggs are more expensive than those of conventional ones. 
When the market prefers these products, the expensive housing systems will sustain with different names and production diversities.

\section{ACKNOWLEDGEMENT}

This study was financially supported by the Scientific Research Project Board of Mustafa Kemal University, Project No: 11462.

The autors also thanks to Prof.Dr. Ahmet ŞAHIN (Ahi Evran University Agri Faculty Anim Sci Dept) for the editing in English the final manuscript.

\section{REFERENCES}

Anderson KE and Adams AW (1994). Effects of cage versus floor environments and cage floor mesh size on bone strength, fearfulness and production of single comb White Leghorn hens. Poultry Science. 73: 1233-1240.

Anonim (2015). Tavuk yumurtası, kabuklu. TSE 1068. TSE. Necatibey Cad. No.112 Bakanlıklar/Ankara (Revizyon).

Doğan H (2008). Adana'da satışa sunulan yumurtalarda sunuş çeşitliliği ve kalite değişimi üzerine bir çalışma. Yüksek Lisans Tezi, Çukurova Üniversitesi, Fen Bilimleri Enstitüsü. Zootekni Anabilim Dalı. Adana.

Englmaierová $M$, Tůmová $E$, Charvátová $V$ and Skřivan M (2014). Effects of laying hens housing system on laying performance, egg quality characteristics, and egg microbial contamination. Czech J. Anim. Sci. 59 (8): 345-352.

Hammershoj M and Steenfeldt S (2015). Organic egg production. II: The quality of organic eggs is influenced by hen genotype, diet and forage material analyzed by physical parameters, functional properties and sensory evaluation. Animal Feed Science and Technology. 208: 182197.

Kinnear PR and Gray CD (1994). SPSS for Windows. Department of Psychology Univ. of Aberdeen. UK.

Kouba M (2003). Quality of organic animal products. Livest. Prod. Sci. 80: 33-40.

Krawczyk J, Cywa-Benko K and Wężyk S (2005). Effect of housing system on egg yolk cholesterol levels in native breeds of hens. International Conference "First International Scientific Poultry Days". Nitra, Słovakia, 12-14 September. pages: 18-20.

Küçükyılmaz K, Bozkurt M, Herken EN, Çınar M, Çatı $A U$, Bintaş $E$ and Çöven $F$ (2012). Effects of Rearing Systems on Performance, Egg Characteristics and Immune Response in Two Layer Hen Genotype. Asian-Aust. J. Anim. Sci. 25 (4): $559-568$.

Leyendecker M, Hamann $\mathrm{H}$, Hartung $\mathrm{J}$, Kamphues $\mathrm{J}$, Ring C, Glunder G, Ahlers C, Sander I, Neumann $U$ and Distl $O$ (2001). Analysis of genotypeenvironment interactions between layer lines and housing systems for performance trails, egg quality and bone strength. 2nd Communication: Egg quality traits. Zuchtungskunde. 73: 308-323.

Mineki M and Kobayashi M (1998). Microstructural changes in stored hen egg yolk. J. Poultr. Sci. 35: 285-294.

Mostert BE, Bowers EH and Van Der Walt JC (1995). Influence of different housing systems on the performance of hens of four laying strains. S.Afr.J. Anim. Sci. 25(3): 80-86.

Pavlovski Z, Masic B, Josipovic S and Hopic S (1992). The Effect of System of Housing on The Laying Performance of Hens in Small Flocks. Biotechnologija U Stocarstvu. 8 (1-2): 57-63.

Pavlovski Z, Svetlana V and Masic B. (1994). The Effect of Housing System on External Egg Quality Traits in Small Layers Flocks. Biotehnologija U Stocarstvu. 10 (3-4): 13-20.

Sarıca M and Erensayın C (2009). Tavukçuluk Ürünleri. Türkoğlu M, Sarıca $M$, Editörler. Tavukçuluk Bilimi, Yetiştirme ve Hastalıklar. BeyOfset Matbaacılık. Ankara. 3. Basım. Syf: 89-138.

Şekeroğlu A and Sarıca M (2005). Serbest Yetiştirme (Free-Range) Sisteminin Beyaz ve Kahverengi Yumurtacı Genotiplerin Yumurta Verim ve Kalitesine Etkisi. Tavukçuluk Araştırma Dergisi. 6 (1): 10-16.

Uluocak N (1991). Yumurta büyüklüğü nelere bağlıdır. Teknik Tavukçuluk Dergisi, 72: (25-40).

Van Den Brand H, Parmentier HK and Kemp B (2004). Effect of housing system (outdoor vs cages) and age of laying hens on egg characteristics. British Poultry Science. 45(6): 745-752. 